\title{
Managing a non-profit hospitality platform conversion: The case of Couchsurfing.com
}

\begin{abstract}
Couchsurfing (CS) was founded in 2003 as a non-profit for those interested in creating a common resource for world-wide hospitality exchange and low cost tourism. Built around a non-market communal sharing model, it became a for-profit in August 2011. Applying a discourse relational model approach, this study characterizes how competing discursive articulations over the conversion led to a discursive strategy of moral justification as management sought to retain its non-profit, alternative, democratic imaginary. The study finds that the justifications gained initial appeal, but ultimately lost credibility due to a mismanaged conversion. By articulating the competing discourses through the sacred value protection model (SVPM), this study provides insights into the way in which a management strategy can be interpreted at a micro-analysis level. It recommends that management decisions need to start from the activities of the organizations members, groups and networks so as to account for their emotions, motivations and actions.
\end{abstract}

\section{Keywords}

nonprofit; communal sharing; volunteer management; tourism; relational model; couchsurfing; hospitality

\section{Introduction}

Couchsurfing (CS) was founded after a software programmer named Casey Fenton found a last-minute ticket to Iceland in 1999. To experience a 'real Iceland' through the people who lived there, he hacked into the University of Iceland student directory 
and 'spammed' students with requests for advice. He received more than fifty replies with offers of accommodation and assistance. In January 2003, Fenton along with Dan Hoffer, Sebastien LeTuan, and Leonardo Bassani de Silveira, launched CS as an intermediating technology platform that facilitated exchange activities. If you needed temporary accommodation, the CS platform would enable you to identify someone to give over sleeping space in their home for free. While CS was not the first hospitality exchange platform, its beginnings became a key 'focus' from which members developed a shared identity. It drew, connected and served a geographically dispersed network of strangers based around shared beliefs, norms of participation and attitudes towards hospitality, openness, tolerance, communal sharing, ethical invigoration and intercultural exchange (Mikołajewska-Zając, 2017).

Official 'Couchsurfing Values' and a 2008 mission statement which envisioned 'a world where everyone can explore and create meaningful connections with the people and places they encounter' offered the raw material for a shared culture (Picard \& Buchberger, 2013). Participation was not market based, as each member acted on principles other than economic profit. Stories of trust, altruism and intimacy circulated despite differences in individual socio-economic background, ethnicity and self-interest (Dén-Nagy \& Király, 2009). The community did not see CS as a business, but as a medium or tool with no corporate office, salaries or advertising. The homogeneity, trust, and reciprocity amongst the membership base (Liu, Nie, \& $\mathrm{Li}$, 2016; Rosen, Lafontaine, \& Hendrickson, 2011) became an inventive force as they constructed a community around communal-sharing expectations and behavior (Schöpf, 2015). The interpersonal relationships built through the platform were based on clear communal goals that were distinguished from the for-profit hospitality marketplace of hotels, hostels and Airbnb (Andriotis, \& Agiomirgianakis, 2014; Celata, Hendrickson, \& Sanna, 2017; Chung, 2017; Steylaerts, \& Dubhghaill, 2012). 
The co-founders fostered and embodied these communal ideas through repeated moral stances in management discourse, with Fenton noting that 'Couchsurfing is the first website of its kind to be owned and operated by the community itself, It's a revolutionary concept' (Prweb, 2006).

Between 2003 and 2011, CS operated as a non-profit under the guidance of Fenton as Executive Director and Dan Hoffer, who dealt with the business end. CS grew organically through word of mouth, and by 2006, had 50,000 members (Prweb, 2006). Funding was based on user donations and a voluntary US\$25 address 'verification' system launched in 2009. Community-based governance (Adler, 2001) led to an organizational structure formed in 2007 with five main teams: Leadership Team (renamed as Strategy Team in 2009), Operations, Community Operations, Marketing \& Communication, and Product Development. By December 2009, the platform had 1 million members with 1,000 key volunteers facilitating growth (Gross, 2009). The volunteer-supported phenomenon ran CS teams such as the 'Contact' Help Desk, Groups Management Team, Media Response Team, Member Disputes and Safety Team and the Translation Team. As volunteers believed they were working for a non-profit, the site became entirely dependent upon their labour as the site grew to 3 million members by 2011. Between 2004 and August 2011, CS raised nearly US\$6 million through direct donations, merchandise sales, and the address verification scheme, with US\$2 million raised in 2010 alone (Feldman, 2012; New Hampshire Corporate Division, 2017).

During August 2011, Fenton announced that CS was changing its legal designation away from non-profit. CS was sold, repurchased by Fenton and Hoffer, and took on investors as it went private. The change was promoted by Fenton and Hoffer as a conversion to a socially responsible B Corporation (Couchsurfing, 2011c), and was seen by many CS members as such. However, legally, the non-profit was 
dissolved, and was replaced by a new for-profit corporation bearing the same name. To investigate the conversion and subsequent impact on volunteers and management, this study uses a discourse relational model. This is not meant to explain a methodological case, but offer a study of a conversion of an innovative non-profit that many see as kick starting the sharing economy phenomenon, and disrupting travel, tourism and hospitality sectors globally (Cheng, 2016). With its 15 million members worldwide, CS was built on a basis from which many social, charity and B-Corp enterprises have recently emerged (Sheldon, Dredge, Daniele, Sheldon, \& Daniele, 2017). The study will conclude with practical guidance on management of communal experiences, resources, norm and relationships within such organizations.

\section{Methodology}

This study uses a discourse relational model approach that consists of a latent content analysis using the software package MAXQDA 2018, to interpret discursive constructions in the data, and then articulate the analysis through a model. A latent content analysis involves a search for implicit meanings embedded in texts to explore what was said, done and shown, financed and technologized. The initial content analysis sought to examine the discourses at the structural level by an analysis of trace evidence in relation to the conversion. These systematically evaluated 'social facts' (Atkinson \& Coffey, 1997) or discourses included the CS wiki (deleted in 2009), management issued videos (since removed from the CS site), CS blog posts (blog.couchsurfing.com), press releases and management emails/newsletters to the community (since removed, but archived at www.opencouchsurfing.org). Much of the official CS data was deleted by the management post-conversion, using the argument that pre-and-post CS had become different legal entities. 
In particular, the audience-directedness of CS blog articles, press releases and emails/newsletters yielded data, excerpts and quotations. This discourse is important as pre-conversion, they helped formulate, disseminate and sustain the desired alternative social imaginary of collaborative production and consumption in a non-profit. This had a tangible impact on social reality of CS volunteers and members. The analysis also allowed us to explore the change in discursive strategy of management post-conversion, and any disjuncture between the projected discourse and the 'reality' as perceived by volunteers as the conversion was implemented (Jacobs, 1999). This 'reality' or second stage was a discourse analysis of discussion posts from the CS ambassador group (1,793 members) between August 2011 (pre-conversion) and August 2013 (post-conversion). This provided a microanalysis of volunteer narratives (Hart, 2010). This discussion group was created in January 2006 and archived in August 2013, before deletion in early 2016. Ambassadors were volunteers who deeply felt the CS purpose. These official (but uncompensated) ambassadors were part of 'an organization structure to support volunteers' and were described as 'experienced CS members who contribute their time to activities that support the CS community' (CS, 2008). All forum discussions mentioning the keywords 'conversion', 'for-profit' and 'non-profit' were identified, and downloaded locally during October 2014. A manual check of all forum discussions between August 2011 and August 2013 also took place. After identifying relevant discussion posts relating to the conversion $(n=836)$, the post threads were anonymised and uploaded to MAXQDA.

The messy, contextual and conflictual discussion posts were critically analysed and coded, so as to examine whether they were supporting (SO) or sceptical (SC) to the conversion, with a code of ' 0 ' for neutral stance. While partially interpretative given the unstructured nature of the text, and not easily susceptible to reliability tests, the 
analysis identified competing discursive articulations and meanings around the conversion. When viewed longitudinally and time-lined, the data indicated that negative sentiment towards the conversion and management worsened over time. The data was compared to particular events, press releases, media reports and management initiatives (Neuendorf, 2002). As the discursive battles regarding the conversion evolved, the readings sought to explore how official and ambassador discourses converged and diverged. The second reading fed the recoded data through a relational model (RM) to focus on the relational aspects between management and ambassadors. The sacred value protection model (SVPM) proposed and developed by Fiske and Tetlock (1997) and Tetlock, Kristel, Elson, Green, and Lerner (2000) assert that when sacred values come under secular assault, people struggle to protect their private-selves and public identities from moral contamination by the impure thoughts and deeds implied in taboo proposals. While the SVPM has previously been used to examine intergroup social image (Täuber \& van Zomeren, 2012) and religious and pharmaceutical marketing (McGraw, Schwartz, \& Tetlock, 2012), it has not been used in tourism management literature. Tetlock (2002) argues that trade-offs can provoke moral outrage when there is an inappropriate extension of market-pricing relational schema to spheres of activity regulated by the other Fiskean (1991) schemata such as communal sharing. The model underwent a lengthy and iterative development process by the authors to ensure the SVPM accurately captured the discursive battles over the conversion (Rusbult \& van Lange, 2003).

As a strategy to add richness and colour to this research and to enable the reader to draw their own conclusions from the ambassadors' own words, verbatim quotations were incorporated along with other social facts. Whilst not all comments reflect all elements in the model, patterns in the overall data were congruent. Quotes were edited according to standards for using verbatim quotations (Corden \& Sainsbury, 2006) and 
consist of enough cases to examine the convergences (and divergences) of views before, during and after the conversion. The study proposal received ethical approval.

\section{Relational model: The SVPM}

The SVPM model is based on the moral economy concept and relational models (RM) theory, which has been theoretically and empirically validated (Haslam, 2004). The moral economy concept was first elaborated by the historian E.P. Thompson (1971; 1993), who argued that peasant villagers held deeply ingrained notions of what was fair and just. These beliefs were often at odds with the budding market ethos when essentials were sold for more than what people could afford. In essence, the peasants expected their society to function according to a moral economy and operate "within a popular consensus as to what were legitimate and what were illegitimate practices' (Thompson, 1971, p. 79) and when essential moral obligation regarding a 'fair price' was not met, moral outrage led to overt acts of resistance (Götz, 2015). Scholars have applied the concept to a range of contexts to describe norms of fairness and legitimacy within a given moral universe, with Molz (2013) and Mikołajewska-Zajac (2017) invoking the concept to describe the communal values within CS. Fiske (1991) argues that the moral economy (of sharing) is related to his relational model of communal sharing, which generates, interprets, coordinates types of social interaction and relationships. Communal Sharing is one of four relational models proposed by Fiske, alongside authority ranking, equality matching, and market pricing. Individuals 'use each of the four fundamental models to organize transfers of material or nonmaterial goods and services and to provide obligatory or ideal standards for such transitions' (Fiske, 1993, p.51).

Communal sharing values were built into the infrastructure of CS by collaboration, mutuality and cultural labour with ambassadors defending these values 
and the people and tools that supported them. As the co-founders cultivated communal sharing values after filling for non-profit status in New Hampshire in 2004, the platform attracted members who saw the co-founders and the platform as constructing and communicating altruism, transparency, inclusion and collaboration. These values were both implicitly and explicitly treated as "possessing infinite or transcendental significance that precludes comparisons, trade-offs, or indeed any other mingling with bounded or secular values' (Tetlock et al. 2000, p. 853). Most CS members believed the platform was subject to communal-sharing obligations and viewed relationships between members, as well as investments in time, labour and donations in non-market terms, given the exchanges created through the platform were not open to the monetary trade-offs prevalent in the commercial hospitality sector (Bialski, 2007). Fenton garnered support through the ambassador program, with deep interdependence and mutual altruism supporting volunteer efforts (Roccas \& McCauley, 2004). This was established on the basis of trust built over multiple and frequent contacts at CS work 'collectives' in various locations such as Canada (2006), Austria (2006), New Zealand (2006/2007), the Netherlands (2007), Thailand (2007/2008), Alaska (2008), Costa Rica (2009) and Turkey (2009/2010).

The communal sharing model is built on harmonious relations based on intimacy, altruism, selflessness, generosity, sharing, and concern for others. People consider resources as common and do not need to give something in order to get something in return (Fiske, 1992). This in turn leads to members to engage in service co-creation and volunteering, given its congruent with the notion of pooling resources. All parties are mutually dependent on each other, creating relationship characterized by deep interdependence (Sheppard \& Sherman, 1998), where 'the completion of one's own consequential activities depend upon the prior actions or ongoing cooperation of another' (Sitkin \& Roth, 2006, p. 298). Communal principles of control (e.g. peer 
pressures, work symbols and ideologies, interaction rituals) and a model which is intrinsically motivating (Fiske, 2004) produced volunteer teams who treated CS as a joint responsibility (Fiske, 1992). These volunteers were highly committed to CS, where commitment is the degree to which the relationship 'is so important as to warrant maximum efforts at maintaining it' (Morgan \& Hunt, 1994, p. 23). In contrast, the market pricing model is built on individuals existing without community as bounded discrete actors mediated through a market system and values.

However, as in many organizations built on communal sharing, a lack of proper record keeping, precise procedures and reporting responsibilities (Kirsch \& Choudhury, 2010) were lacking. While the co-founders filed in New Hampshire to incorporate CS as a 501(c)(3) in March 2004, it wasn't added to the list of registered charities in the state until November 2007. This led the Department of Justice in New Hampshire to investigate CS for failing to fully register as a non-profit and non-payment of federal tax. The lack of federal tax-exempt status hindered tax exceptions for donations and led CS to seek 501c3 charity status in late 2007. In 2010, New Hampshire's director of charitable trusts questioned whether CS met the conditions for its public charity status in the state (Kamph, 2013). By late 2010, the IRS advised CS they would decline the 501c3 application (Longenecker, Moore, \& Petty, 2016). Fenton and Hoffer's lawyer advised them their only option was to become a for-profit (Lapowsky, 2012). In March 2011, the IRS (2011) stated CS couldn't guarantee the charitable activity of its members and denied the application. CS filled a petition on April 7, 2011, asking New Hampshire's attorney general's office permission to dissolve itself. A tax and auditing firm, Grant Thornton (2010) valued assets at just under US\$640,000 in a report published on December 31st, 2010. The cofounders petitioned a New Hampshire court for authorization to buy the assets itself, telling the court that nobody else could receive the assets and that there were no 
interested parties to be notified of the plan to sell CS. The judge approved the move on July 6 and the assets were sold to the C-Corporation 'Better World Through Travel' (BWTT) incorporated in Delaware on May 3rd, 2011 for US\$637,800. The majority shareholders of BWTT were Fenton and Hoffer. They issued shares to themselves and sold a minority share for US\$7.6 million to venture capital firms, Benchmark Capital and Omidyar Network to gain investment. They also paid off federal back-taxes to the IRS, paid legal fees and provided US\$600,000 to a New Hampshire Charitable Foundation. In June, the company filed for the right to do business in California and was renamed CouchSurfing International Inc. with Hoffer as CEO. The original CS was legally dissolved in November 2011.

While some key volunteers in a Team Member News Special Bulletin were told on April 16, 2011 that changes were coming, Fenton only informed the ambassadors on August 23 that CS was to become a Certified B Corporation (B-Corp) (Chen \& Kelly, 2014). On August 24, 2011, Fenton sent a three page note to 1,000 key volunteers and an email (CS, 2011a) to the community announcing that CS had become a B-Corp, and had accepted investment capital. While the announcement saw Fenton receiving over 1,500 emails questioning whether the communal sharing relationships could be reconciled with what on the surface seemed a move towards a market pricing model (Lapowesky, 2012), the ambassadors default cognitive reaction was to show loyalty (Kaltcheva, Patino, Laric, Pitta, \& Imparato, 2014). In the model, justifications are accepted when it is difficult to process information and weigh the credibility of claims (Gilbert, Krull, \& Malone, 1z990; Tetlock, 2002). Given the deep interdependence between management and ambassadors, only a minority of ambassadors out rightly rejected the conversion. While Matt, France, Aug 25, 2011 asked 'We didn't get that money for free, did we? What's in for them?,' most ambassadors, such as Jack, Jason, and Alan wanted to wait and see. 
Personally I would've preferred it still being a non-profit, but with the system not really built to handle all this traffic that millions of members generate, some extra cash to put into better coding so we don't have to endure all these 'system down' messages, I'll be a happy camper. Jack, Sweden, Aug 27, 2011.

I understand much of the blocks on 'modernisation' of the site has been as a result of conditions imposed by the 503c application process....then now that the blocks are removed, fingers crossed... :) Jason, Scotland, Aug, 24, 2011.

Apparently Casey is smart enough to partner up with such people, who I know it's hard to believe may not have the almighty dollar as their motive in life. The money they invested in CS is like a nickel to you and me. Just maybe they are interested to see what good CS can do besides make a profit for the nickel they invested. I think we will be okay folks. Alan, United States, Aug 27, 2011.

Even though ambassadors were a separate equivalence class, the communal sharing model permits 'differentiation or contrast, but no numerical comparisons' (Fiske \& Tetlock, 1997, p. 258). As consensus and unity through communication are the expressions of communal decision making, ambassadors had come to expect consultation in delivering a well-functioning platform. They had expected the co-founders to ask the community to pool resources to fulfil collective needs without seeking the aid of outsiders. Matt, Czech Republic, August 29, 2011 noted that 'It just seems a bit unfair to change the direction like this from NGO to Corp. Casey never asked to help, I am sure we would find 1 million in donations.' CS management failed 
to anticipate ambassador concerns over consultation, dialogue, seeking resources from outsiders as well as the obligation not to omit information.

Accompanying the announcement to convert were communally-focused justifications for the conversion. In a series of videos produced by a PR Agency (Moreau, 2011), Fenton explains 'Even though being a non-profit has been a major defining feature of CouchSurfing, it isn't Couchsurfing's core identity.' Fenton and Hoffer were put through an intensive media-training program (Lapowsky, 2012) and organized a 12 city world city tour by Fenton starting September 2011 where he (management) promised to be accountable to all the people who had a stake in CS (Fenton, 2011a; Couchsurfing, 2011c). McGraw and Tetlock (2005) argue organizations have considerable public-relations latitude and resources to craft and communicate effective reframing messages to justify norm violations and assuage distress over market-pricing strategies. The co-founders believed ambassadors could be assured that the cash infusion would not foster market practices. Rather than structure the decision as a taboo trade-off, which is defined as 'any explicit mental comparison or social transaction that violates deeply held normative intuitions about the integrity, even sanctity, of certain forms of relationships and of the moral-political values that derive from those relations' (Fiske \& Tetlock, 1997, p. 256), the decision was structured as a tragic trade-off, where management was forced to make a decision to keep the community alive (Chorus, Pudāne, Mouter, \& Campbell, 2017). Fenton and Hoffer sought to reframe the market-pricing strategy as communally-focused by framing the normative breach into something less distressing (Aaker, Fournier, \& Brasel; 2004; McGraw, Schwartz, \& Tetlock, 2012). The main justification was that the IRS would never allow CS to qualify as a non-profit and that income did not keep up with the network's growth. The IRS was faulted as the outsiders who made the incorrect interpretations. Initial communication with volunteers did not explicitly 
mention it was now a C-Corporation, and only noted that it had received a B-Corp certification with funding from socially minded and philanthropic investors (Couchsurfing, 2011a). Fenton argued that CS was now a social enterprise, which meant it could focus on things other than profit. Press releases on August 24 (Krubner, 2011) and August 26 (Business Wire, 2011) and an email to the community on August 27 (Couchsurfing, 2011b) failed to indicate the new legal status, Fenton argued that:

Just because we're not a non-profit doesn't mean we're actually 'for' profit. CouchSurfing is not for sale, and money is not our goal. We recognize that the community is what makes this movement real and supporting it is what our organization is here for. Everyone on our staff is a CouchSurfing member, and we want to keep it that way.

The communally focused relational justifications meant resistance was initially mute, with an October 2011 change.org petition against the conversion receiving only 882 signatories. However, extensions of market-pricing norms discovered by members disturbed the values that were meant to be infinitely important. Ambassador anger grew as details emerged about the lack of paperwork and how a pre-conversion valuation of US\$637,800 could result in a US\$7 million investment for a minority stake. Questions emerged as to why CS hadn't appealed or applied for other non-profit statuses. Members also noted that the B-Corp designation had no legal basis, and was a tool often utilised by for-profit corporations to suggest they were not a 'real' for-profit corporation (Stammer, 2016; Wohler, 2011). Ambassadors in late 2011 began to question why CS was relabelled as a 'start-up' organization with a CEO, stock options, venture capitalist investors and a new San Francisco office 
complete with in-house chef (Farr, 2012; Saiidi, 2016). As anti-conversion groups began advocating resistance and ways they could reverse the transition and/or agitate against it, Fenton and Hoffer became to be seen as hypocritical by not reaffirming their commitment to communal values (Kreps, Laurin, \& Merritt, 2017).

Given that trust within the communal sharing mode is based on deep interdependence, a byproduct of the conversion was the risk of management being accused of betrayal if they were perceived to be acting in their own interests. Having not enough insight on the risk side meant the perceived lack of commitment to the fundamental nature of communal relationships by Fenton and Hoffer led ambassadors to believe the conversion as a violation of values. Although bound by community norms to 'subordinate profit-seeking to the needs of the community' (Martin \& Schouten, 2013, p.868), Hoffer was found to have announced that the conversion was the first step towards an initial public offering (IPO) (Reventós, 2011). He also admitted he had written up a contract with Fenton to detail what would happen if CS were to ever go for-profit (Txakeeyang, 2011). Members found out Hoffer had been working as an 'Entrepreneur In Residence' (Sep 2010 - Aug 2011) at the same Benchmark Capital who invested in CS. The profile of new investors, pictures of the San Francisco office and a new management team with commercial pasts suggested a conspicuous market approach. Kreps et al. (2017) using meta-analyses of 15 studies argue that when leaders change their moral minds, audiences view them as less effective and less worthy of support. Given the perception that Fenton and Hoffer were willing to misrepresent the conversion led ambassadors to believe the co-founders had made the 'wrong' choice in a taboo trade-off. Hoffer stood down as CEO in April 2012 (CS, 2012a) to become president (CS, 2012b). Fenton blogged in June 2012 that he and Hoffer were stepping back from the day-to-day involvement (CS, 2012c). 
The company brought in Tony Espinoza, who had served as vice president at AOL and MTV Networks and as CEO of several internet start-ups. Whilst Espinoza promised no major charges (CS, 2012e) after a further US\$15 million was raised in August 2012 (CS, 2012d), a site redesign and rewriting of backend code replaced the code that volunteers had written. The volunteer based activities of the support team and the safety team were outsourced, and the Locations Team, Groups Management Team, Event Message Approval Team, the Verifications Team, the Translations Team, Contact Us Questions (CUQ) Team and Bug Submission Team were closed. New 'Terms of Service' were introduced, along with salaried staff (Roudman, 2013). Espinoza's lack of prior history in CS or non-profits created fragile interpersonal relations with ambassadors and stimulated a questioning of whether Espinoza and the new staff were committed to a shared moral vision. Ambassadors initially believed that Espinoza should adhere to the communal sharing norms and values, and share the work with them to move the project forward. Instead, clashes between the new CEO and ambassadors began in December 2012 when management replaced or culled most of its city groups which had been painstakingly build as 'wiki' styled portals and forums, with travel information and advice. The replacement 'Place Pages' did not have the features of the old groups, such as the search function, permalinks, privacy controls and moderator control. Matt, United Kingdom, Dec 6, 2012 explained:

Congratulations - you, and the team you work with, are well on the way to wrecking the greatest community I have ever been a part of. The Groups was the bedrock of the community, the social side of CS. And the 'Places pages', far from being an improvement, have basically bulldozed much of the community side of that, in favour of something that looks more like any generic attempt at a social media platform. 
Even though management changes would be perfectly valid in another context, ambassadors felt they had little control over a tool they used to promote and self-organize communal relationships. Peter, Sweden, February 26, 2013 argued 'We have been stripped of any helpful tools to help us help the community' while Michael, Germany, March 5, 2013 wrote 'it hurts me to see that something many hundreds of people spend many ten-thousands hours within many years to improve it, make it big, gets destroyed by some people who don't care what they do.' As further changes to key tools such as the method of organizing CS events took place, there was increased conflict between ambassadors and paid CS staff on the forum. Jackson, England, March 4, 2013 argues that 'It's our house, and our show, and without us they have nothing. They are our guests - and we permit them to use us and our data to make themselves money - in exchange for taking responsibility for shepherding this community.' Ambassadors sought to distinguish themselves as a community from the new legal entity, with Tony, France, Aug 26, 2012 stating that 'A CS ambassador is here to develop his local CS community. It is not directly to promote the CS website, but to develop connections between people. The CS website is only the tool which permits it.' Travis, Germany, Aug 27, 2012, argued that 'the CS community is a different entity from CS International Inc.' while Elaine, Netherlands, Aug 27, 2012 argued that 'The community was created by and as a non-profit, not by a company.'

For management, the steps were rational as they moved towards a market pricing model, which required the replacement of those informal systems applicable to communal sharing exchanges (Blois \& Ryan, 2012). These social locations are difficult to manage and monetize (Perren \& Kozinets, 2018). However, the changes to informal systems were too rapid and were carried out without consolation. Ambassadors felt they were neither listened to nor respected, with their agency and voice threatened by the perceived appropriation of their participation by the 
co-founders, investors and new staff who demanded a smooth transition towards market values. While Lisa, Perth, Feb 23, 2013 argued that 'Do you understand the depth and breadth of experience, passion and amazing people you have at your fingertips if only you gave them the chance? Currently the only thing happening is alienation of everyone who would support you,' Roger, March 4, 2013 noted 'unfortunately for Cs corp, they didn't study or understand the ready built community and expertise I heard Tony [Espinoza] bragging about to investors.' The decisions to strip away systems, tools and content led many ambassadors to conclude that management values were not aligned with their communal values. Rather than receive continuity, conformity and adherence from the new CEO, two critical CS ambassadors for Chicago and Berlin had their profiles deleted in February 2013 (Shetler, 2013). Given equivalence under a principle of collective belonging and solidarity, the abuse of members of their own kind saw a vitriolic backlash on the forums. New restricted forum guidelines were introduced in February 2013, to discourage ambassadors from promoting other hospitality platforms or criticise paid staff. As dissent grew about perceived censorship, hierarchy, profile deletions and the redesigns, there was a notable change in member attitude. A September 2012 avaaz.org petition received 5200 signatories by explaining:

We, the community of CouchSurfing, are the ones who built everything from scratch in voluntary work. Many of us still are doing everything to keep the spirit of CouchSurfing alive, even if it's getting more and more difficult...As this community was giving such a high social reward to all its users, and as we won't just watch how this all is destroyed by the profit-seeking shareholders, we decided to fight for the future of our community and will do our best to put it back to the track of the user based community it has been for a long time! 
Each contestation about reconfigured terms of use, redesign, the ambassadorship role, and the potential of 'unqualified members' joining (Schouten \& McAlexander, 1995) led to moral outrage. Each change to the inclusive and social infrastructure build by volunteers came to be seen as illegitimate practices that threatened the wellbeing of the whole community, and the values associated with communal relationships. Rather than a sharp disjunction between management and ambassadors, taboo trade-offs slowly contaminated ambassador's moral identity (Tetlock, 2002) to create moral cleansing, in which individuals aim to restore moral self-worth in response to perceived moral transgressions (Rai \& Fiske, 2011; Tetlock et al. 2000; Tetlock, 2002). Moral outrage within the SVPM model posits that when people discover that members of their community such as decision makers have compromised sacred values, they experience an aversive arousal state that has cognitive (e.g. negative dispositional attributions), affective (e.g., anger, disgust, shame), and behavioral components (e.g. ostracism of transgressors). The SVPM model also postulates that the longer observers believe that decision makers contemplate compromising sacred values, the more intense the outrage they direct at those decision makers. As outrage at management missteps intensified, many ambassadors engaged in moral cleansing to reaffirm 'core values and loyalties by acting in ways that shore up those aspects of the moral order that have been undercut by the transgression' (Tetlock et al. 2000, p. 854).

By early 2013, a more sustained wave of criticism emerged on social and mainstream media (Shetler, 2013). As a protesting strategy, individual ambassadors contacted the mainstream media and build campaign structures on YouTube and blogs to affect the (public) image of CS. The main target was Espinoza, who many believed was planning to fully commercialize the community. His lack of any social bonds to 
ambassadors and perceived lack of internalisation of CS values, 'in which one adopts another's beliefs because they are congruent and integrated with one's own' (Sheppard \& Sherman, 1998, p. 430) meant his efforts were seen as 'polluting' violations that tainted communal sharing relationship (Fiske, 1992). Their attacks meant he was seen part of the objectified 'they' rather than the subjective 'we' (Fiske, 1992). Despite him reaching out on the forums and temporarily hiring an established ambassador as a Community Manager, the CEO and the ambassadors were using 'different models to generate different aspects of the same interaction and to make sense of it from different points of view' (Fiske, 1992, p. 711).

Conflict between ambassadors and management intensified when the company abruptly ended the Ambassador Programme in early 2013 (CS, 2013b), and restarted it with different terms and conditions. Management sought to verify the identity of each reapplying ambassador using their passports, gauge their activity to measure their performance and re-apply to post conversion CS values. The guidelines were morally distressing given within the model; parties don't require written and detailed specifications, procedures, and rules 'because they know what needs to be done, given their 'sameness' with the others' (Kirsch \& Choudhury, 2010, p. 316). Shelly, Australia, May 24, 2013 said 'I won't be reapplying for the new program. If I have to be measured and judged to keep pretty meaningless flag, it's not something I'm interested in.' Dec, Edward and Sam argued that communal norms were been undermined:

Our old guidelines were about being inclusive, tolerant, open, and trying to be the best CSers we can be. This new list of guidelines ...reads more like the 10 Commandments. Instead of outlining how ambassadors can work together to develop 
community, they're about keeping ambassadors from harming the company. Dec, United States, February 23, 2013

I don't remember signing any loyalty pledges to Couchsurfing. I do remember volunteering to help point people in my community. Couchsurfing is a culture that you cannot buy because you have VC funds. I suppose you can grab a database that was funded by donations and try to monetize it but that doesn't mean you bought my loyalty whilst doing so. I owe you nothing. Edward, United States, March 20, 2013

CS has been trying to turn all of us ambassadors into corporate prostitutes. I've been an ambassador for around 4 years now. While it used to feel like I was doing great work, now I feel like I - and all future ambassadors are looked at as nothing more than corporate shills. The proposed program seeks more to create specialized brand-builders, not community developers. Sam, United States, May 29, 2013

Management was no longer trusted on to do what is required to nurture communal relationship. Ambassadors morally 'cleansed' themselves through boycotts, political lobbying, negative word of mouth and resistance to co-optation (Thompson \& Coskuner-Balli, 2007). Ambassadors felt they became the product being sold, along with their symbolic capital, connections, volunteering, and the community they had built. Changes became to be seen as part of a recurrent pattern of taboo-trade-offs, discursive framing and agenda-setting that supported the move to a market pricing model. Even though investment was intended for platform 'upgrades', ambassadors felt changes were undermining the community. Ritchie, London, April 16, 2013 argued: 
Casey had previously accepted millions of man hours in events, hosting, volunteer coders, word of mouth spreading, to help build CS. We built this community, and gave CS a saleable value. "WE" the users contributed what makes couchsurfing.org valuable. "THEY" the founders sold it without our asking or permission, or even any advance notice whatsoever! And out of venture capital money that was only possible because of what WE gave to this community. YOU and your team are not putting value into couchsurfing community. The community investment has already been done, by us. I understand you plan to rebuild the website to a high standard. That will never be enough to us who made this community.

CS members trusted each other and the co-founders to hold up their end of an implicit agreement grounded in deontic principles and mutual understandings about communal sharing (Luo \& Zhang, 2016). Trust made it possible to share a commons, rights and responsibilities designated by their ability and needs. However, an organic, self-organized base with autonomous ambassadors was not compatible with a for-profit whose fiduciary duty was to investors who sought self-reinforcing growth. Many ambassadors felt trust, accountability and communication were replaced by 'management by orders and dictates' (Jane, Netherlands, Dec 29, 2012). Shelly, Australia, Feb 22, 2013 argued that 'Communication, transparency and the willingness to be open with your members are a choice, not something driven by corporate status,' while Billy, Feb 20, 2013 noted that 'How many times have we asked - some of us even begged - them to give us advance notice of important changes that impact the community.' The lack of communication reinforced the tension between the moral and market logics and created contradictions, conflicts, and schisms between management and ambassadors, as well as between the new members who joined after the conversion and old members. Matt, United Kingdom, February 
20, 2013 argued that 'How sad that things that have taken years to build up can be so quickly destroyed. Trust between the site owners and amongst members has broken down - and without that we no longer have a community.' Kate, Denmark, February 21, 2013 wrote, 'They do not make me trust that CS is still our community and that I have any influence over it now. They did not make me feel I and people around me are any important to CS.' Trevor, United States, February 21, 2013 wrote:

CSHQ had its own agenda, and evidently a transparency problem, and instead of also extending its hand in friendship, it bit the hands that fed it, spit in faces, in some warped strategy to perhaps show that there was a new sheriff in town. Much of what CSHQ has done since has been to antagonize the active base, ignoring suggestions that would improve the site, dismissing calls not to move ahead with specific changes - if they even bothered to notify members of upcoming changes - and beating their chests with threats to delete and censor.

While doubling numbers to 7 million, launching a mobile app and securing further funding (CS, 2013a), Espinoza's lack of shared background and vision meant he could not span boundaries or exercise control. The CEO and ambassadors were unable to make sense of each other's behaviour, coordinate, and redress wrongs seen by both sides, with his attempts at building trust undermined by the contradictory contractual formality he progressively introduced. His inability to govern by any particular model led to his resignation in October 2013. Jen Billock, who has been director of member experience at CS became interim CEO and was made permanent in August 2014 (Brown, 2014; Burns, 2014; CS, 2014). The new CEO decided to rebuild the site from scratch again and dilute the last remaining aspects of pre-conversion CS. While Billock worked to use the data generated by the community 
to offer advertisements, as well as partner with travel and tourism companies, there was no clear business model, as she too confronted the difficulties of moving across boundaries towards a market pricing model. While failing to impose control, dissent also failed to re-impose the moral economy, with Thompson (1963, p. 73) writing that eighteenth century food riots were 'a last desperate effort by the people to reimpose the older moral economy as against the economy of the free market.'

Many dissenting members left the CS ecosystem by choice, suspension or exhaustion. While Sophie, United Kingdom, February 20, 2013 noted that 'I have finally given up on caring about things I have spent 4-5+ year nurturing and caring for,' others began to self-organize outside CS. Sarah, United States, March 4, 2013 wrote 'We will make a difference... maybe just not on the CS platform we had thought.' Fabian, Australia, Dec 27, 2012 noted that 'The website can come and go, but there are many other places that you can stay in contact.' Sean, Feb 24, 2013 noted 'Why waste any more energy trying to help a company that has such disregard for you or anything you have to offer? Take your spirit of volunteerism and use it someplace where it is truly needed, but above all, appreciated.' A side effect of the conversion was that many members set out to create or revitalise non-profit alternatives such as warmshowers.org which gained 501(c)(3) Tax Exemption status in 2014, trustroots.org and bewelcome.org. Billock resigned in October 2015, and was replaced by Patrick Dugan who has never communicated in any form to media or members. After CS withdrew or was expelled as a B-Corp in early 2016, Dugan has pushed verification and a 'freemium' package to broker relationships through data based tools. While communal aspects of the community have eroded with normative breaches, with unconditional giving and strong in-group feelings declining, CS remains sensitive to its pre-conversion history. CS cannot yet be fully detached from its communal sharing past as a resistant legacy is built in. While a market pricing 
relational model has not manifested itself in purely economic terms, CS has settled on a hybrid model, which combines aspects of communal and market-based exchange. These combined logics can be seen other communities, such as geocaching and 'Burning Man,' where consumers partially collaborate with entrepreneurs (Kozinets, 2002; Scaraboto, 2015).

\section{Discussion: Managing trust and relationships in the communal sharing model}

Organizational leaders often speak about creating communities around their products and services, rather than recognizing that they are more often courting existing communities with their own histories, hierarchies, traditions, and practices. The hospitality exchange community that co-constructed CS and its values existed before CS with many ambassadors having left a platform called 'hospitalityclub.org' because of the absence of any legal status as well as issues with management transparency. While the communal sharing model provides management with resources and opportunities, such as volunteer commitment and deep interdependence, this study shows that management needs to fully recognise the associated risks. The communal creation of digital resources over the last decade has created new spaces for non-market and non-profit forms of communal and commons-based economies. These communal sharing structures bring demands 'to coordinate with others, to judge each other, and as a standard to which they demand that others conform' (Fiske, 1992, p. 700) rather than top down mechanisms to punish violations of the "spirit of payment" as in market based exchanges (Perren \& Kozinets, 2018).

The emergence of sharing economy platforms such as Airbnb, indicate how hybrid profit-non-profits or so called social enterprises cultivate relationships characterized by deep interdependence so as to facilitate economic interactions. As of April 2017, there were over 2,000 certified B-Corps across 50 countries, including 
tour operators, NGOs and tourist attractions. As the number of organizations exploiting diverse platform aspects and interactions based on communal sharing within the tourism and hospitality sectors increase (Richard \& Cleveland, 2016; Sharp, 2018), changes to modes of operation in system of governance can present fundamental challenge to basic value systems. For example, once monetary value is placed on non-profit services (Weisbrod, 1998), relationships with clients and funders can change and lead to trade-offs (Blois \& Ryan, 2012). When decisions to go for-profit or commercialise may be based on rational, calculated and strategic choices by management, bubbles of sameness and connection are broken when sudden changes cause mis-anticipation of needs and behaviours. Etsy, a certified B-Corp which emphasized the importance of human interaction saw employee, management and membership turmoil after an Initial Public Offering (I.P.O) in 2015 (Gelles, 2017), while the commercialisation of Tripadvisor between 2012-2015 saw numerous volunteer revolts (Kinstler, 2018). This study highlights how a mismanaged replacement of a highly social and communal system with a market based one, can lead to committed 'communal sharers,' and supporters of a sharing ideology to protest and resist management and disagree with less committed members.

As the study uses a relational model not previously used in tourism and hospitality management literature before, the model can offer guidance to management thinking whether it's possible to move members from a communal sharing model. The model also acts as a diagnostic tool and instructive guide for management thinking about the tensions between relational models, and the importance of member and employee views when making decisions. Rather than conclude that management cannot change models and or that venture capitalists should think twice before intervening in the affairs of an organization where the communal sharing relational model is manifest (Martin \& Schouten, 2014), our 
analysis shows that attention must be paid to 'the activities of individuals, groups and networks of people upon which key processes and practices depend' (Johnson, Melin, \& Whittington, 2003, p.14). By doing so, management in contexts other than CS, may be better placed to retain members through collaboration and coordination in order to create or retain trust whilst reducing uncertainty and vulnerability during periods of change.

Kozinets (2002) argues members contributing to an organization, should be allowed to actively contribute to any move towards a hybrid or market based exchanges whilst retaining some nonmarket logics of mutuality and interdependence. Our analysis showed goodwill towards management after the initial management announcement, as members were led to believe that the conversion was about 'communal sharing,' and protecting collective goods. It indicates the possibility of slowly moving CS members towards market logic. However, as the full and immediate privatisation of CS became apparent, members believed their capacities for interactions based on communal sharing parts were threatened and good will evaporated. Our analysis shows that significant mistakes were made. This study suggests that within organization utilising a communal model, management must recognize that members of the community have a stake in the organization and grant them greater influence by inviting them to play a role in any changes. This required that CS management tell the community what was going on and focus on greater transparency, disclosure and honesty. Management should have worked with the ambassadors to communicate changes to members, with Kay, Feb 20, Germany noting 'Do you remember the time we had 'collectives' deciding on the future of the community and working together?'. The analysis showed that the strategy to hide the dissolution of CS, pacify the community by way of public relations, and 'greenwash' (Donia \& Sirsly, 2016) change by utilising the self-certifying B-Corp standard failed. 
While this strategy may have been developed to reduce disagreement with members, management came to be seen as disingenuous as 'communal sharers' found evidence of managements lack of substantive coherence, consistency, commitment, unity, loyalty and commitment to communal-sharing norms. The analysis shows that subsequent management teams from outside CS never fully recognised CS as a collective resource and subject to communal sharing norms. The analysis also indicates that members felt the investment should also have been viewed as common property, and invested back into the CS community, rather than benefiting only the cofounders and new salaried staff sourced from outside the community. Management should have recognised those members, who invested their donations, labour and time into the project. There should have been full disclosure of the percentage of equity held by the new investors, the financial benefits to the co-founders, and full disclosure surrounding the benefits and costs of conversion as well as any alternatives.

\section{Conclusion}

The management decision to move CS away from its communal foundations to take a more commercial stance has come to seen as a 'critical event' by scholars, CS management, volunteers and members. This study found the SVPM offered explanatory potential for the real and consequential breakdown of relationships between CS management and ambassadors, and helped identify the missteps that led ambassadors to see the conversion as threatening the very source of culture on which CS emerged, as well as the social and psychological needs it met. The study helped to highlight how management changes to organisations build on a communal-sharing system can have profound implications for all stakeholders.

\section{References}


Aaker, J., Fournier, S., \& Brasel, S. A. (2004). When Good Brands Do Bad. Journal of Consumer Research, 31 (June), 1-16.

Adler, P. S. (2001). Market, Hierarchy, and Trust: The Knowledge Economy and the Future of Capitalism. Organization Science, 12(2), 215-234.

Andriotis, K., \& Agiomirgianakis, G. (2014). Market escape through exchange: Home swap as a form of non-commercial hospitality. Current Issues in Tourism, 17(7), $576-591$.

Atkinson, P. A. \& Coffey, A. (1997). Analysing documentary realities. In D.

Silverman (Ed.), Qualitative research: Theory, method and practice (pp. 45-62). London: Sage.

Avaaz.org (2012). For a strong Community behind CouchSurfing. Retrieved from https://secure.avaaz.org/en/petition/For_a_strong_Community_behind_CouchSurfing Ayers-Greenidge, E. (2012). Free Associations: An Exploration Of Guests' Experiences In The Couchsurfing Exchange. Wright Institute.

Bialski, P. (2007). Intimate Tourism: Friendships in a State of Mobility-the Case of the Online Hospitality Network. Warsaw: University of Warsaw.

Blois, K., \& Ryan, A. (2012). Interpreting the nature of business to business exchanges through the use of Fiske's Relational Models Theory. Marketing Theory, 12(4), 351-367. 
Bowen, G. A. (2009). Document analysis as a qualitative research method.

Qualitative Research Journal, 9(2), 27-40.

Brown, K.V. (2014). A rough ride to profit for CouchSurfing. Nov 26.

http://www.sfgate.com/business/article/A-rough-ride-to-profit-for-CouchSurfing-5920 089.php

Business Wire (2011). CouchSurfing Raises \$7.6 Million in Series A From

Benchmark Capital and Omidyar Network to Expand Services and Fuel Growth in Cultural Exchange Network. Aug 25. Retrieved from http://www.businesswire.com/news/home/20110825005488/en/CouchSurfing-Raises7.6-Million-Series-Benchmark-Capital

Burns, H. (2014). She's trying to turn Couchsurfing into a profitable business. And she's got her hands full. Bizjournal, Oct 22. Retrieved from http://www.bizjournals.com/bizwomen/news/profiles-strategies/2014/10/shes-trying-t o-turn-couchsurfing-into-a-profitable.html

Celata, F., Hendrickson, C. Y., \& Sanna, V. S. (2017). The sharing economy as community marketplace? Trust, reciprocity and belonging in peer-to-peer accommodation platforms. Cambridge Journal of Regions, Economy and Society, 10(2), 349-363.

Change.org (2011). Petition against the new legal status of CouchSurfing. Retrieved from https://www.change.org/p/petition-against-the-new-legal-status-of-couchsurfing 
Change. Org (2014). Give CouchSurfers Their 'Usable' Web-site back - a.k.a. - Roll Back the CS Design to Pre-November 2014. Retrieved from https://goo.gl/GY4Va0814

Chen, X. \& Kelly, T. F. (2014). B-Corps-A Growing Form of Social Enterprise:

Tracing Their Progress and Assessing Their Performance. Journal of Leadership \& Organizational Studies, 22(1), $102-114$.

Cheng, M. (2016). Sharing economy: A review and agenda for future research. International Journal of Hospitality Management, 57, 60-70.

Chorus, C.G., Pudāne, B., Mouter, N., \& Campbell, D. (2017). Taboo trade-off aversion: A discrete choice model and empirical analysis, Journal of Choice Modelling (in press).

Chung, J.Y. (2017). Online friendships in a hospitality exchange network: a sharing economy perspective, International Journal of Contemporary Hospitality Management, 29(2), 3177-3190.

Corden, A., \& Sainsbury, R. (2006). Using Verbatim Quotations in Reporting Qualitative Social Research: The Views of Research Users. York: University of York.

Couchsurfing (2008). Homepage. Retrieved from http://www.CouchSurfing.org/ 
Couchsurfing (2011a). A New Era for Couchsurfing. Aug 24. Retrieved from http://blog.couchsurfing.com/a-new-era-for-couchsurfing/

Couchsurfing (2011b). A letter from co-founder Casey Fenton. Aug 27. Retrieved from http://blog.couchsurfing.com/a-letter-from-co-founder-casey-fenton/

Couchsurfing (2011c). Myths and Facts: Couchsurfing's conversion to a B Corp. Sep 14. Retrieved from http://blog.couchsurfing.com/myths-and-facts-couchsurfings-conversion-to-a-b-corp/ Couchsurfing (2012a). A letter from Dan Hoffer. Feb 20. Retrieved from http://blog.couchsurfing.com/a-letter-from-dan-hoffer/

Couchsurfing (2012b). Announcing our new CEO. April 25. Retrieved from http://blog.couchsurfing.com/announcing-our-new-ceo/

Couchsurfing (2012c). A letter from Casey. June 28. Retrieved from http://blog.couchsurfing.com/a-letter-from-casey/

Couchsurfing (2012d). Couchsurfing raises $\$ 15$ million to improve our website and mobile apps! August 22. Retrieved from http://blog.couchsurfing.com/couchsurfing-raises-15-million-to-improve-our-websiteand-mobile-apps/

Couchsurfing (2012e). What does more funding mean for Couchsurfing? A conversation with CEO Tony Espinoza. Aug 24. Retrieved from 
http://blog.couchsurfing.com/what-does-more-funding-mean-for-couchsurfing-a-conv ersation-with-ceo-tony-espinoza/

Couchsurfing (2013a). The Future of Couchsurfing. July 2. Retrieved from http://blog.couchsurfing.com/the-future-of-couchsurfing

Couchsurfing (2013b). Our Couchsurfing Ambassador Program. Oct 16. Retrieved from http://blog.couchsurfing.com/our-couchsurfing-ambassador-program

Couchsurfing (2014). Couchsurfing HQ Leadership Update. Aug 11. Retrieved from http://blog.couchsurfing.com/leadership-update/

Dén-Nagy, I., \& Király, G. (2014). How to Explain CouchSurfing's Success? Szociológiai Szemle, 24(4), 32-53.

Donia, M.B., \& Sirsly, C.A.T. (2016). Determinants and consequences of employee attributions of corporate social responsibility as substantive or symbolic. European Management Journal, 34(3), 232-242.

Farr, C. (2012). Startup culture series: At Couchsurfing, employees may take time off to travel the world, October 5. Retrieved from http://venturebeat.com/2012/10/05/couchsurfing/

Feldman, Z. (2012). Beyond freedom and oppression: Social media, refusal and the politics of participation. In Selected Papers in Internet Research: IR 13.0 Technologies. 
Fenton, C. (2011a). What happened to 501c3? Oct 1. Retrieved from https://caseyfenton.wordpress.com/2010/10/01/what-happened-to-501c3/

Fenton, C. (20011b). What becoming a B Corp means for Couchsurfing. Nov 1. Retrieved from https://caseyfenton.wordpress.com/2010/11/

Fenton, C (2012). A letter from Casey, June 28, Retrieved from http://blog.couchsurfing.com/a-letter-from-casey/

Fiske, A. P. (1991). Structures of Social Life: The Four Elementary Forms of Social Relations. New York: Free Press.

Fiske A. P. (1992). The four elementary forms of sociality: Framework for a unified theory of social relations. Psychological Review, 99, 689-723.

Fiske, A. P. (2004). Relational models theory 2.0. In N. Haslam (Ed.). Relational Models Theory: A Contemporary Overview (pp. 3-25.). Mahwah, NJ: Erlbaum

Fiske, A., \& Tetlock, P. E. (1997). Taboo trade-offs: Reactions to transactions that transgress spheres of justice. Political Psychology, 18, 255-297.

Gelles, D. (2017). Inside the Revolution at Etsy. New York Times, Nov 25. Retrieved from https://www.nytimes.com/2017/11/25/business/etsy-josh-silverman.html 
Gilbert, D. T., Krull, D. S., \& Malone, P. S. (1990). Unbelieving the Unbelievable: Some Problems in the Rejection of False Information. Journal of Personality and Social Psychology, 59, 601-13.

Götz, N. (2015). Moral economy: its conceptual history and analytical prospects. Journal of Global Ethics, 11(2), 147-162.

Grant Thorton (2011). CouchSurfing International, Inc. Fair Market Value As of December 31, 2010. June 21. Retrieved from https://sites.google.com/site/cskbase/npo-privatization/GrantThorntonvaluationCS.pdf

Gross, M. (2009). Three Cushions, a Million Guests. New York Times. April 8. Retrieved from http://frugaltraveler.blogs.nytimes.com/2009/04/08/3-cushions-a-million-guests/ Hart, C. (2010). Critical discourse analysis and cognitive science: New perspectives on immigration discourse. Basingstoke: Palgrave Macmillan.

Haslam, N. (Ed.). (2004). Relational Models Theory: A Contemporary Overview. Mahwah, NJ and London: Lawrence Erlbaum Associates.

IRS (2011). Letter 4036(CG)(11-2005) Retrieved from http://www.irs.gov/pub/irs-wd/1125045.pdf

Jacobs, G. (2009). Projected discourse: An analysis of receiver roles in press releases. Text - Interdisciplinary Journal for the Study of Discourse, 18(4), 505-524. 
Johnson, G., Melin, L. \& Whittington, R. (2003). Micro Strategy and Strategizing: Towards an Activity based View, Journal of Management Studies, 40(1), 3-22.

Kaltcheva, V.D., Patino, A., Laric, M. V., Pitta, D. A., \& Imparato, N. (2014).

Customers' relational models as determinants of customer engagement value. Journal of Product \& Brand Management, 23(1), 55-61.

Kamph, S. (2013). Loose Stuffing: How Couchsurfing lost its kumbaya, The

Magazine, Issue \#14, April 11. Retrieved from

http://the-magazine.org/14/loose-stuffing

Kinstler, L. (2018). How TripAdvisor changed travel. The Guardian. Aug 17.

Retrieved from

https://www.theguardian.com/news/2018/aug/17/how-tripadvisor-changed-travel

Kirsch, L. J., \& Choudhury, V. (2010). Toward a theory of relational control: How relationship structure influences the choice of controls. In S. B. Sitkin, L. B. Cardinal, \& K. M. Bijlsma-Frankema (Eds.), Organizational Control (pp. 301-323). Cambridge: Cambridge University Press.

Kozinets, R. V. (2002). Can consumers escape the market? Emancipatory illuminations from burning man. Journal of Consumer research, 29(1), 20-38. 
Kreps, T. A., Laurin, K., \& Merritt, A. C. (2017). Hypocritical Flip-Flop, or Courageous Evolution? When Leaders Change Their Moral Minds. Journal of Personality and Social Psychology, 113(5), 730-752.

Krubner, L. (2011). More innovation from CouchSurfing. Smash Company. Aug 28. Retrieved from http://www.smashcompany.com/business/more-innovation-from-couchsurfing Lapowsky, I. (2012). Couchsurfing Dilemma: Going for Profit. Inc. Retrieved from http://www.inc.com/magazine/201206/issie-lapowsky/couchsurfing-new-profit-model $\underline{. h t m l}$

Laclau, E. and Mouffe, C. (1985). Hegemony and Socialist Strategy: Towards a Radical Democratic Politics, 2nd ed., Verso, New York, NY.

Liu, Y., Nie, L., \& Li, L. (2016). Homogeneity, trust, and reciprocity: Three keys to the sustainable hospitality exchange of couchsurfing. Tourism Analysis, 21(2-3), $145-157$.

Longenecker, J. G., Moore, C. W., \& Petty, J. W. (2016). Small Business Management: Launching \& Growing Entrepreneurial Ventures. Cengage Learning,

Luo, Q., \& Zhang, H. (2016). Building interpersonal trust in a travel-related virtual community: A case study on a Guangzhou couchsurfing community. Tourism Management, 54, 107-121. 
Martin, D. M., \& Schouten, J. W. (2013). Consumption-driven market emergence. Journal of Consumer Research, 40(5), 855-870.

Mikołajewska-Zając, K. (2017). Terms of reference: The moral economy of reputation in a sharing economy platform. European Journal of Social Theory, 1-21.

McGraw, A.P., \& Tetlock, P.E. (2005). Taboo trade-offs, relational framing and the acceptability of exchanges. Journal of Consumer Psychology, 15, 2-15.

McGraw, A. P., Tetlock, P. E. \& Kristel, O. V. (2003). The Limits of Fungibility: Relational Schemata and the Value of Things. Journal of Consumer Research, 30, 219-29.

McGraw, A.P., Schwartz, J. \& Tetlock, P. (2012). From the commercial to the communal: Reframing taboo trade-offs in religious and pharmaceutical marketing. Journal of Consumer Research, 39(1), 157-173.

Molz, J. G. (2013). Social Networking Technologies and the Moral Economy of Alternative Tourism: The Case of CouchSurfing.org. Annals of Tourism Research, 43(1), 210-230.

Moreau, N. (2011). New Profit Era for CouchSurfing. Retrieved from http://en.inmoreau.com/963/new-profit-era-for-couchsurfing-interview-video/ Morgan, R.M. \& Hunt, S .D. (1994). The commitment-trust theory of relationship marketing. Journal of Marketing, 58, 20-38. 
Neuendorf, K. A. (2002). The content analysis guidebook. London: Sage.

New Hampshire Corporate Division (2017). Couchsurfing international Inc. Retrieved from https://www.sos.nh.gov/corporate/soskb/Filings.asp?473515\#

Picard, D. \& Buchberger, S. (Eds.). (2013). Couchsurfing Cosmopolitanisms: Can Tourism Make a Better World? Bielefeld: Transcript Verlag.

Prweb (2006). A Strong Web Community Refused to Die. Montréal, Quebec, Canada. July 13. Retrieved from http://www.prweb.com/releases/2006/07/prweb410431.htm

Reventós, L. (2011). 13 Sept, El jefe de CouchSurfing asegura que su objetivo es salir a Bolsa. El Pais. Sep 13. Retrieved from http://elpais.com/diario/2011/09/13/radiotv/1315864802_850215.html

Richard, B., \& Cleveland, S. (2016). The future of hotel chains: Branded marketplaces driven by the sharing economy. Journal of Vacation Marketing, 22(3), 239-248.

Rosen, D., Lafontaine, P. R., \& Hendrickson, B. (2011). CouchSurfing: Belonging and trust in a globally cooperative online social network. New Media \& Society, 13(6), 981-998. 
Roudman, S. (2013). How to Lose Funds and Infuriate Users: Couchsurfing, a Cautionary Tale From the 'Sharing Economy' Techpresident. Nov 7. Retrieved from http://techpresident.com/news/24498/couchsurfing2

Rusbult, C. E., \& Van Lange, P. A. M. (2003). Interdependence, interaction, and relationships. Annual Review of Psychology, 54, 351-375.

Saiidi, U. (2016). Office Envy: Inside CouchSurfing's San Francisco workspace. CNBC. Feb 12. Retrieved from http://www.cnbc.com/2016/02/12/couchsurfings-awesome-sf-workspace.html Scaraboto, D. (2015). Selling, sharing, and everything in between: The hybrid economies of collaborative networks. Journal of Consumer Research, 42(1), 152-176.

Schöpf, S. (2015). The Commodification of the Couch: A Dialectical Analysis of Hospitality Exchange Platforms. TripleC, 13(1), 11-34.

Schouten, J. W., \& McAlexander, J. H. (1995). Subcultures of consumption: An ethnography of the new bikers. Journal of consumer research, 22(1), 43-61.

Sharp, D. (2018). Sharing Cities for Urban Transformation: Narrative, Policy and Practice. Urban Policy and Research, 1-14. 
Sheppard, B. H., \& Sherman, D. M. (1998). The Grammars of Trust: A Model and General Implications. The Academy of Management Review, 23 (3), 422-437

Shetler, S. (2013). Couchsurfing faces backlash from some members after censorship charges. Quirky Travel Guy. March 9. Retrieved from http://quirkytravelguy.com/couchsurfing-censorship-community-backlash-tony-espin $\underline{\text { ozal }}$

Sitkin, S .B., \& Roth, J.A. (2006). Legalistic 'remedies' for trust/distrust. In R.M Kramer (Ed.), Organizational Trust (pp. 295-330). Oxford: Oxford University Press.

Stammer, R. (2016). It Pays to Become a B Corporation. Harvard Business Review. Sep 6. Retrieved from https://hbr.org/2016/12/it-pays-to-become-a-b-corporation

Steylaerts, V., \& Dubhghaill, S. O. (2012). CouchSurfing and authenticity: Notes towards an understanding of an emerging phenomenon. Hospitality \& Society, 1(3), 261-278.

Täuber, S., \& van Zomeren, M. (2012). Refusing intergroup help from the morally superior: How one group's moral superiority leads to another group's reluctance to seek their help. Journal of Experimental Social Psychology, 48, 420-423.

Tetlock, P. E. (2002). Social-functionalist metaphors for judgment and choice: The intuitive politician, theologian, and prosecutor. Psychological Review, 109, 451-472. 
Tetlock P. E., Kristel, O. V., Elson, S. B., Green, M. C., \& Lerner, J. S. (2000). The Psychology of the Unthinkable: Taboo Trade-Offs, Forbidden Base Rates, and Heretical Counterfactuals. Journal of Personality and Social Psychology, 78(5), 853-70.

Tetlock, P. E. \& McGraw, A. P. (2005). Theoretically Framing Relational Framing. Journal of Consumer Psychology, 15(1), 35-37.

Thompson, C. J., \& Coskuner-Balli, G. (2007). Countervailing market responses to corporate co-optation and the ideological recruitment of consumption communities. Journal of Consumer Research, 34(2), 135-152.

Thompson, E.P. (1963). The Making of the English Working Class. London: Victor Gollancz Ltd/Vintage Books.

Thompson, E. P. (1971). The Moral Economy of the English Crowd in the Eighteenth Century. Past \& Present, 50, 76-136.

Thompson, E. P. (1991). The Moral Economy Reviewed. In Customs in Common, 259-351. London: Merlin.

Thompson, E. P. (1993). Customs in Common: Studies in Traditional Popular Culture. New York: New Press. 
Txakeeyang, L. (2011).Couchsurfing Co-founder and former CEO Daniel Hoffer Discusses Leadership at the Stanford Graduate School of Business. The Stanford Daily: The Daily Dish. 21 Oct.

Weisbrod, B. A. (1998). The nonprofit mission and its financing: Growing links between nonprofits and the rest of the economy. In B. A. Weisbrod (Ed.), To profit or not to profit: The commercial transformation of the nonprofit sector (pp. 1-24). New York, NY: Cambridge University Press.

Wohler, M. (2011). CouchSurfing Moves from NGO to B-Corps: Bona fide or Bogus. Triplepundit. Retrieved from http://www.triplepundit.com/2011/09/couchsurfing-corporation-bona-fide-bogus/ 